\title{
Clinical Study of Retraction Pockets in Chronic Suppurative Otitis Media
}

\author{
Srikanth Myla ${ }^{1}$, Ramesh Elma ${ }^{2}$
}

\begin{abstract}
A clinical study was undertaken to evaluate the total incidence of retraction pockets in chronic suppurative otitis media patients admitted in ENT ward of SVS Medical College and Hospital.Clinical study of retraction pockets regarding aetiological factors, the pathogenesis in the chronic suppurative otitis media patients selected.Thorough evaluation regarding presenting symptoms, signs associated with retraction pockets in the patients selected.Studyof surgical procedure adopted for treatment of retraction pockets in the patients selected. Post operative follow-up and success rate of surgical procedures adopted for retraction pockets in the patients selected.
\end{abstract}

Keywords: Retraction pockets,sinus tympani, facial recess, cholesteatoma, posterior tympanotomy.

\section{Introduction}

Chronic suppurative otitis media is a persistent disease of mucoperiosteal lining of middle ear cleft. This disease often causes severe destruction and irreversible sequelae, involving the tympanic membrane, ossicles and the temporal bone. It manifests clinically as discharge and deafness of variable severity. It can be subdivided into active or inactive depending on presence or absence of infection and mucosal or squamous depending on middle ear mucosa or squamous epithelium of tympanic membrane involvement.

Management of Retraction Pocket can be optimally planned and realized only in case of having a thorough knowledge on its pathogenesis, behaviour, localization of the retraction pocket as well as the anatomic and functional factors and ossicular chain involvement.

Retraction Pockets are known to be the precursors of cholesteatoma formation so the retraction pockets in earlier stages have to be strategically treated. The impairment of ventilation between the Eustachian tube and the aditus is very important in the pathogenesis of retraction pocket formation so, maintaining or re-creating the pathways again will serve for better success. The surgical plans should be based on the locations of the retraction pocket in order to have a better exposition of the retraction pocket and to remove it completely. It is important to establish the most efficient way of reaching to the retraction pocket even if it is located in sinus tympani or anterior epitympanic recess. May be the endoscopes can serve us for better control in these cases. One of the most important factors determining for the type of surgery is the presence of mastoid air cells. The sclerotic mastoids as being the evidence of impaired ventilation should force us for creating small cavities in common with the middle ear and external auditory canal. But the most important is preserving the mucosa which is known as the lungs for the middle ear.Retraction pocket especially for the posterior superior quadrant is commonly invaded by retraction pockets and/or granulation tissue, visualization and eradication of the disease from this area is critical. But also there appear difficulties of accessing to this area and handling the disease located inside. The sinustympani is located medial to the facial nerve and this makes it impossible to access here by using operating microscopes. During the second half of the twentieth century the technique posterior tympanotomy has been defined for access to posterior mesotympanum (Jansen C.1958) ${ }^{69}$. With this access the bone between fossa incudis, facial canal and the chorda tympani is drilled and a window is created posteriorly to open the middle ear. With this technique the access to the facial recess is completely possible. The long process of the incus, incudo-stapedial joint, stapes, stapedial muscle, the pyramidal process and the round window is under the view through this window however accessing to the tympanic sinus will still be limited.

\section{Aims \& Objectives of the Study}

This study was conducted with following objectives: A study of incidence of total retraction pockets i.e., attic retraction pockets \& posterior superior retraction pockets. Study of retraction pockets by staging, Study of visualization of ossicular status by examination under microscope. Audiological study of hearing loss in posterior superior retraction pockets.Role of posterior tympanotomy approach in posterior superior retraction pockets.

\section{Materials and Methods}

In our department we conducted a prospective study on combined approach Tympanoplasty with intact canal wall with posterior tympanotomy approach on 47 patients during a period from August 2012 - August 2013. These patients presented to our hospital with different Ear symptoms e.g. ear discharge and hearing loss.

Inclusion Criteria:Only cases in which posterior superior retraction pocket are present were included in this study.Differentiation between stages was based on Sade J (1979) classification. The patients ranged in age from 11 to 50 years.All patients were subjected to full ENT history and examination.

Exclusion criteria: Paediatric age group - less than 10 years. Patientsage group above 50 years. Clinically unsafe ears i.e. with cholesteatoma, intracranial complication, malignant or tubercular ear disease. Incomplete removal of the tympnomastoid disease, inadequate exposure due to severely contracted mastoid, extensive canal wall destruction. When patient cannot come for follow up postoperatively. All patients evaluated by detailed history and otologic assessment and documentation through 


\section{International Journal of Science and Research (IJSR) \\ ISSN (Online): 2319-7064 \\ Index Copernicus Value (2013): 6.14 | Impact Factor (2014): 5.611}

photography were done through otoendoscopy. Audiological evaluation was done by tuning fork tests and pure tone audiometry. Pure tone average and bone conduction at 500 $\mathrm{Hz}, 1 \mathrm{KHz}, 2 \mathrm{KHz}, 4 \mathrm{KHz}$ and $8 \mathrm{KHz}$ recorded. Examination under microscope is done for conformation.

\section{Methods}

We used combined approach Tympanoplasty with intact canal wall with posterior tympanotomy approach for all cases of Grade III \& IV posterior superior retraction pockets.

\section{Analysis}

Results were analysed for Grade III \& IV retraction pockets for visualization of ossicular status, audiological evaluation of hearing loss, various pathologies observed, ossicular integrity, ossicular status in contrast to examination under microscope, efficacy of disease clearance.

\section{Observations}

The study was conducted in ENT OPD of SVS Medical College \& Hospital during the period of August 2012August 2013. It is observed an average No. of 80-90 patients per day visit to our OPD.

Table 1: Showing incidence of CSOM Variety in ENT OPD.

\begin{tabular}{|c|c|}
\hline CSOM Variety & No of Patients $($ Percentage $)(n=6264)$ \\
\hline Safe CSOM & $4385(70 \%)$ \\
\hline Unsafe CSOM & $1880(30 \%)$ \\
\hline
\end{tabular}

It is observed that total No. of CSOM cases were 6264 per year. It is observed out of which safe variety of CSOM were 4385 patients and unsafe CSOM were 1880 patients. The results in Table. 1

Table 2: Showing incidence of unsafe CSOM according to age group.

\begin{tabular}{|c|c|}
\hline Age Group & $\begin{array}{c}\text { No of Unsafe CSOM Patients } \\
\text { (Percentage })(n=1880)\end{array}$ \\
\hline$<10$ years & $169(9 \%)$ \\
\hline $11-20$ years & $545(29 \%)$ \\
\hline $21-30$ years & $507(27 \%)$ \\
\hline $31-40$ years & $358(19 \%)$ \\
\hline $41-50$ years & $94(5 \%)$ \\
\hline$>50$ years & $207(11 \%)$ \\
\hline
\end{tabular}

Age group below 10 years and above 50 years were excluded from the study. It is observed that 1504 patients in the age group of 10-50 years were of unsafe CSOM. The results are tabulated in Table. 2

Table 3: Showing distribution of retraction pockets \&cholesteatoma between age group of 11-50 yrs.

\begin{tabular}{|c|c|}
\hline Type of Unsafe CSOM & $\begin{array}{c}\text { No of patients } \\
\text { (percentage) }(\mathrm{n}=1504)\end{array}$ \\
\hline Definitive cholesteatoma & $664(45 \%)$ \\
\hline Retraction pocket & $840(55 \%)$ \\
\hline
\end{tabular}

It is observed that in 664 were having definitive cholesteatoma and were treated by modified radical
Mastoidectomy and were not included in the study and the results are tabulated in Table. 3

Table 4: Showing distribution of retraction pockets

\begin{tabular}{|c|c|}
\hline Type of Retraction Pocket & $\begin{array}{c}\text { No. of patients } \\
\text { percentage })(n=840)\end{array}$ \\
\hline Attic retraction pocket & $633(75 \%)$ \\
\hline Posterior superior retraction pocket & $207(25 \%)$ \\
\hline
\end{tabular}

It is observed that in 1504 patients with retraction pockets, 207 patients had posterior superior retraction pocket and 633 patients had attic retraction pocket and the results are tabulated in table. 4

Table 5: Showing distribution of attic retraction by Tos (1988) staging.

\begin{tabular}{|c|c|}
\hline $\begin{array}{c}\text { Attic retraction pocket } \\
\text { grade (Tos 1988) }\end{array}$ & $\begin{array}{c}\text { No.patients } \\
\text { (perentage)(n=633) }\end{array}$ \\
\hline Grade I & $222(35 \%)$ \\
\hline Grade II & $285(45 \%)$ \\
\hline Grade III & $84(13 \%)$ \\
\hline Grade IV & $42(7 \%)$ \\
\hline
\end{tabular}

Table 6: Showing distribution of posterior superior retraction pockets by Sade (1979) Staging

\begin{tabular}{|c|c|}
\hline $\begin{array}{c}\text { Posterior superior retraction } \\
\text { pockets (Sade 1979) }\end{array}$ & $\begin{array}{c}\text { No.patients } \\
\text { perentage })(n=207)\end{array}$ \\
\hline Grade I & $69(35 \%)$ \\
\hline Grade II & $91(44 \%)$ \\
\hline Grade III & $30(15 \%)$ \\
\hline Grade IV & $17(8 \%)$ \\
\hline
\end{tabular}

It is observed that in 207 patients with posterior superior retraction pockets, 160 were in Grade I \& II, these were treated conservatively. 47 patients were having Grade III \& IV; they were treated by posterior tympanotomy approach and will be our study and the results are tabulated in table.6.

Table 7: Showing incidence of grade III \& IV retraction pockets

\begin{tabular}{|c|c|}
\hline Retraction pocket in Grade III \& IV & $\begin{array}{c}\text { No. of patients } \\
\text { (Percentage })(n=177)\end{array}$ \\
\hline Attic & $126(73 \%)$ \\
\hline Posterior superior retraction pocket & $47(27 \%)$ \\
\hline
\end{tabular}

It is observed that the total No. of patients having Grade III \& IV retraction pockets were 177 , out of them 126 patients $(73 \%)$ were in attic and $47(27 \%)$ were in posterior superior quadrant of pars tensa. The results were tabulated in table.7

It is observed that the total No. of patients having retraction pockets were 840 . Out of them $633(75 \%$ )was having in attic and 201(25\%) were having in posterior superior quadrant of pars tensa. The results were tabulated in table.4.It is observed that the total no of patients having attic retraction were 633. Grading was done by Tos M (1988) classification. Out of them 222(35\%) were Grade I, 285(45\%) were Grade II, $84(13 \%)$ were Grade III and $42(7 \%)$ were Grade IV. The results are tabulated in Table.5.

It is observed that the total No. of patients having posterior superior retraction pockets were 207. Grading was done by Sade J (1979) classification. Out of them 69(33\%) were Grade I, 91(44\%) were Grade II, 30(15\%) were Grade III 


\section{International Journal of Science and Research (IJSR) \\ ISSN (Online): 2319-7064 \\ Index Copernicus Value (2013): 6.14 | Impact Factor (2014): 5.611}

and $17(8 \%)$ were Grade IV. The results are tabulated in Table.6.

Table 8: Showing hearing loss A-B gap in grade III \& grade IV posterior superior retraction pocket.

\begin{tabular}{|c|c|c|c|}
\hline Grade & $\begin{array}{c}\text { Hearing loss 25- } \\
\begin{array}{c}40 \mathrm{~dB}(\mathrm{n=23}) \text { No. } \\
\text { of patients } \\
\text { (percentage) }\end{array}\end{array}$ & $\begin{array}{c}\text { Hearing loss more } \\
\text { than 4OdB }(n=24) \\
\text { No. of patients } \\
\text { (percentage) }\end{array}$ & $\begin{array}{c}\text { Total No. } \\
\text { Of patients } \\
\text { (percentage) }\end{array}$ \\
\hline $\begin{array}{c}\text { Grade } \\
\text { III }\end{array}$ & $13(28 \%)$ & $17(36 \%)$ & $30(64 \%)$ \\
\hline $\begin{array}{c}\text { Grade } \\
\text { IV }\end{array}$ & $10(21 \%)$ & $7(15 \%)$ & $17(36 \%)$ \\
\hline
\end{tabular}

It is observed that out of 30 patients with Grade III posterior superior retraction pocket, 17 (36\%) had hearing loss more than $40 \mathrm{~dB}$ and $13(25 \%)$ had $25-40 \mathrm{~dB}$ loss. It is observed that out of $17(36 \%)$ patients with Grade IV posterior superior retraction pocket, $7(15 \%)$ patients had hearing loss more than $40 \mathrm{~dB}$ and $10(21 \%)$ had $25-40 \mathrm{~dB}$ hearing loss. It is observed that conductive hearing loss of $25-40 \mathrm{~dB}$ in $49 \%$ and hearing loss of more than $40 \mathrm{~dB}$ in $51 \%$. The results are tabulated in table. 8

Table 9: showing various pathologies found in middle ear

\begin{tabular}{|c|c|c|}
\hline Pathology & $\begin{array}{c}\text { Grade III } \\
(n=30) \\
(\text { Percentage })\end{array}$ & $\begin{array}{c}\text { Grade IV } \\
(n=17) \\
(\text { Percentage })\end{array}$ \\
\hline Glue & $14(47 \%)$ & $17(100 \%)$ \\
\hline Cholesteatoma & $3(10 \%)$ & $6(35 \%)$ \\
\hline Granulations & $24(80 \%)$ & $14(82 \%)$ \\
\hline Granulation+Cholesteatoma & $3(10 \%)$ & $6(35 \%)$ \\
\hline
\end{tabular}

It is observed that in Grade III, Glue is present in $14(7 \%)$, cholesteatoma in 3(6\%) patients, Granulations in $24(80 \%)$ patients and granulations with cholesteatoma in $3(10 \%)$ patients. It is observed that in Grade IV, Glue is present in $17(100 \%)$ patients, cholesteatoma in $6(35 \%)$ patients, Granulations in $14(82 \%)$ patients and granulations with cholesteatoma in $6(35 \%)$ patients. The results are tabulated in Table9.

Table 10: Showing ossicular pathology observed during posterior tympanotomy

\begin{tabular}{|c|c|c|c|}
\hline Pathology & $\begin{array}{c}\text { Grade III } \\
(n=30) \text { No. } \\
\text { of patients } \\
\text { (percentage) }\end{array}$ & $\begin{array}{c}\text { Grade IV } \\
(n=17) \text { No. } \\
\text { of patients } \\
\text { (percentage) }\end{array}$ & $\begin{array}{c}\text { Total } \\
(n=47) \text { No. } \\
\text { of patients } \\
\text { percentage })\end{array}$ \\
\hline $\begin{array}{c}\text { Necrosis of long } \\
\text { process of incus }\end{array}$ & $14(47 \%)$ & $3(18 \%)$ & $17(36 \%)$ \\
\hline $\begin{array}{c}\text { Necrosis of } \\
\text { incudostapedial } \\
\text { complex }\end{array}$ & $19(63 \%)$ & $13(76 \%)$ & $32(68 \%)$ \\
\hline $\begin{array}{c}\text { Necrosis of stapes } \\
\text { suprastructure }\end{array}$ & $14(47 \%)$ & $10(59 \%)$ & $24(51 \%)$ \\
\hline Fibrous adhesions & $14(47 \%)$ & $16(94 \%)$ & $30(64 \%)$ \\
\hline
\end{tabular}

It is observed that in Grade III, necrosis of long process is seen in $14(47 \%)$ patients, necrosis of incudostapedial complex in $19(63 \%)$ patients, necrosis of stapes suprastructure in $14(47 \%)$ patients, fibrous adhesions in 14 (47\%) patients. In Grade IV, necrosis of long process is seen in $3(18 \%)$ patients, necrosis of incudostapedial complex in $13(76 \%)$ patients, necrosis of stapes suprastructure in
$10(59 \%)$ patients, fibrous adhesions in $16(94 \%)$ patients. The results are tabulated in Table. 10

Table 11: Showing efficacy of posterior tympanotomy in disease clearance in grade III \& IV posterior superior retraction pockets

\begin{tabular}{|c|c|c|c|}
\hline Factor taken & $\begin{array}{c}\text { Grade III } \\
\left(\begin{array}{c}\text { (n=30) No. of } \\
\text { patients } \\
(\text { Percentage })\end{array}\right.\end{array}$ & $\begin{array}{c}\text { Grade IV } \\
\left(\begin{array}{c}n=17) \text { No. of } \\
\text { patients } \\
(\text { Percentage })\end{array}\right.\end{array}$ & $\begin{array}{c}\text { Total }(n=47) \\
\text { No. of } \\
\text { patients } \\
(\text { Percentage })\end{array}$ \\
\hline $\begin{array}{c}\text { Complete removal } \\
\text { of disease }\end{array}$ & $30(100 \%)$ & $17(100 \%)$ & $47(100 \%)$ \\
\hline $\begin{array}{c}\text { Ossicular } \\
\text { reconstruction } \\
\text { possible }\end{array}$ & $24(80 \%)$ & $6(35 \%)$ & $30(64 \%)$ \\
\hline Residual disease & $0(0 \%)$ & $0(0 \%)$ & $0(0 \%)$ \\
\hline $\begin{array}{c}\text { Temporary facial } \\
\text { nerve palsy }\end{array}$ & $2(7 \%)$ & $1(6 \%)$ & $3(6 \%)$ \\
\hline $\begin{array}{c}\text { Permanent facial } \\
\text { nerve palsy }\end{array}$ & $0(0 \%)$ & $0(0 \%)$ & $0(0 \%)$ \\
\hline Reperforation & $1(3 \%)$ & $3(18 \%)$ & $4(8 \%)$ \\
\hline $\begin{array}{c}\text { Sensorineural } \\
\text { hearing loss }\end{array}$ & $0(0 \%)$ & $0(0 \%)$ & $0(0 \%)$ \\
\hline
\end{tabular}

It is observed that disease clearance was present in all the cases. Ossicular reconstruction is possible in $30(64 \%)$ patients. There was no residual disease or permanent facial nerve palsy or sensorineural hearing loss.Temporary facial nerve palsy is present in $3(6 \%)$ patients. Results are tabulated in Table. 11

\section{Discussion}

1. Incidence Retraction Pockets.

It is observed in our study an incidence of $25 \%$ retraction in posterior superior quadrant of pars tensa and $75 \%$ of attic retractions. Similar Incidence was found in Luntz $(1997)^{90}$ However, in the study reported by JE.Xenelis ${ }^{229}$ had $41 \%$ of retraction in posterior superior quadrant of pars tensa and $59 \%$ of attic retraction.

\section{A study of retraction pockets by staging}

It is observed in our study an incidence of retraction pockets as $35 \%, 45 \%, 14 \%$ and $7 \%$ of grade I, II, III and IV by Sade classification respectively. Majority of retraction pockets is observed in stage I \& II. However, in the study reported by Borgstein $\mathrm{J}(2007)^{13}$ had incidence of retraction as $22 \%$, $27 \%, 28 \%$ and $23 \%$ in grade I, II, III and IV respectively showing equal number of retraction pockets for each grade. This difference may be due to his study group consisted of children in contrast to our study group which had only adults.

3. Audiological Study of hearing loss in posterior superior retraction pockets.

It is observed in our study to have moderate conductive hearing loss of $25-40 \mathrm{~dB}$ of $43-57 \%$ in Grade III \& IV retraction pocket. However Mills $(1991)^{104}$ have reported an observation of moderate conductive hearing loss of $25-40 \mathrm{~dB}$ in $93 \%$ in all Grades.

4.To study various pathologies like fibrous tissue adhesions, glue, granulations, cholesteatoma.It is observed in our study to have fibrous adhesions in Grade III \& IV to be $47 \%-94 \%$. 


\section{International Journal of Science and Research (IJSR) \\ ISSN (Online): 2319-7064}

Index Copernicus Value (2013): 6.14 | Impact Factor (2014): 5.611

Similar observation were observed by Grewal $(1997)^{56}$ to be $25 \%-82 \%$.It is observed in our study to have cholesteatoma to be $10-35 \%$ in Grade III \& IV retraction pockets which had similar observation of $35 \%$ in the study by V.P.Sood $(1973)^{196}$.It is observed in our study to have granulations in $81 \%$ of Grade III \& IV retraction pockets.

5. To study the ossicular status in contrast to EUM.It is observed in our study to have necrosis of long process of Incus in 36\%, necrosis of Incudostapedial joint in $68 \%$ and necrosis of Stapes superstructure in $51 \%$. These observations were similar to the study by V.P.Sood $(1993)^{196}$.

6. To evaluate the efficacy of disease clearance.It is observed in our study to have disease clearance as $100 \%$ which is similar to other studies by Luntz M (1991) $)^{89}$, Steven Y.Ho $(2003)^{199}$, Yangihara $(1993)^{230}$.It is observed in our study to have re-perforation in $3-18 \%$ of grade III \& IV retraction .All the cases of Grade III \& IV retraction pockets were operated by posterior tympanotomy even though there is no significant hearing loss.

\section{Conclusion}

It is well known fact that retraction pockets are the precursors for cholesteatoma formation. Surgical planning for retraction pockets is based on knowledge for the mechanism of retraction pocket formation, meticulous preoperative evaluation rational application of surgical technique for the patients and individualization of the surgical technique.

Majority of retraction pockets are in attic followed by posterior superior retraction pockets. Majority of posterior superior retraction pockets are in Grade I \& II of Sade J (1979) classification. Conductive hearing loss of more than $40 \mathrm{~dB}$ is present in $51 \%$ and moderate conductive hearing loss of $25-40 \mathrm{~dB}$ in $43-57 \%$ of patients. The common pathology identified is Glue $(100 \%)$, followed by Granulations (80\%), followed by fibrous adhesions (47\%), cholesteatoma $(35 \%)$, cholesteatoma with granulations $(35 \%)$. Incus is damaged in majority of cases followed by stapes, followed by malleus. Necrosis of the incudostapedial joint $(68 \%)$ is present in majority of cases followed by stapes superstructure $(51 \%)$, followed by long process of incus $(36 \%)$.Disease clearance was successful in all the cases. Posteriortympanotomy is successful in clearing the whole disease and able to reconstruct hearing mechanism with good aeration of middle ear with minimal postoperatively complications. Posteriortympanotomy in selected cases is a good option.

\section{Acknowledgement}

Dr Srikanth Myla. Professor of ent .s v s medical college ,yengonda,Mahaboobnagar,Telanganastate.India.

Dr Ramesh Elma. Senior resident, s v s medical college, yenugonda,Mahaboobnagar,Telanganastate.India.

\section{References}

[1] Alex Vlase, VasileCostinescu, THE POSTERIOR TYMPANOTOMY IN THE FUNCTIONAL SURGERY OF THE MIDDLE EAR, J Surg, 2010; 6(3) 305-316, ICID: 920900, Article type: Original article $\mathrm{IC}^{\mathrm{TM}}$ Value: 4.41

[2] Ars BM (1991) Tymapanic membrane retraction pockets. Etiology, pathogeny, treatment.

[3] Borgstein J, Gerritsma T, Bruce I, Feensta L (2009) Atelectasis of the middle ear in pediatric patients: safety of surgical intervention. Int J PedOtorhinol 73: 257-261

[4] Browing G.G. The unsafeness of safe ear. Journal of Laryngotology. 1984; 98:23.26

[5] Cassano M, Cassano P (2010) Retraction pockets of pars tensa in pediatric patients: clinical evolution and treatment. Int J PedOtorhinol 74:178-182

[6] Couloigner V, Molony N, Viala P, Contencin P, Narcy P, Van Den Abbeele T (2003) Cartilage Tympanoplasty for posterosuperior retraction pockets of the pars tensa in children. OtolNeurotol 24 : 264-269 (2003)

[7] Deguine C. Long-term results in cholesteatoma surgery. ClinOtolaryngol 1978; 3:301-10

[8] DelwarHossain, MoslehUddin, AhmmadTaous, KaziShameemus Salam, Rafiqul Islam. Canal wall window tympanomastoidectomy - A review of 84 cases. Bangladesh J Otorhinolaryngol Vol.16, No.1, April 2010

[9] Dornhoffer JL, GB Colvin, P North. Evidence of residual disease in ossicles of patients undergoing cholesteatoma removal. ActaOtolaryngol. 1999 Jan: 119(1): 89-92 